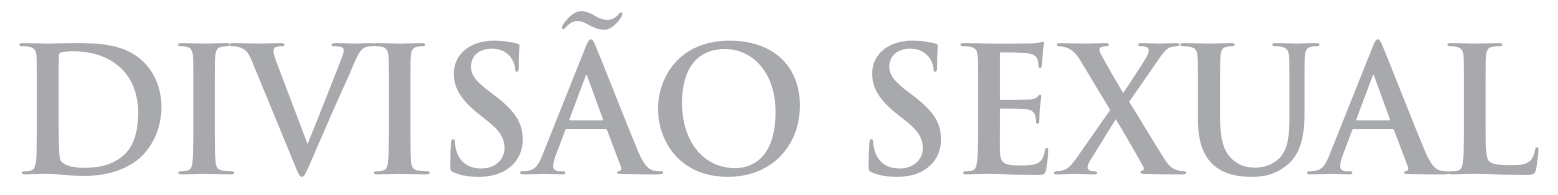

$$
\begin{array}{r}
\text { TRABALHO E RELAÇÕES } \\
\text { GÊNERO EM CONTEX } \\
\text { ESTUARINO-COSTEI } \\
\text { AMAZÔNI }
\end{array}
$$




\section{DIVISÃO SEXUAL DO TRABALHO E RELAÇÕES DE GENNERO EM CONTEXTO ESTUARINO-COSTEIRO AMAZÔNICO}

\section{N O RMA VI E I RA}

UNIVERSIDADE FEDERAL DO PARÁ, BRASIL

D E I S S I QUE I RA

UNIVERSIDADE DE BRASília E UNIVERSIDADE FEDERAL DO PARÁ, BRASIL

$$
\text { M A R C E L L A E V E R }
$$

UNIVERSIDADE FEDERAL DO PARÁ, BRASIL

$$
\text { MARIA GOMES }
$$




\title{
DIVISÃO SEXUAL DO TRABALHO E RELAÇÕES DE GÊNERO EM CONTEXTO ESTUARINO-COSTEIRO AMAZÔNICO
}

\section{Resumo}

$\mathrm{O}$ artigo discute resultados de pesquisas realizadas, de forma articulada, pelo grupo de pesquisa Estudos Socioambientais Costeiros/UFPA, em várias comunidades de populações tradicionais na região da Reserva Extrativista Marinha de Caeté Taperaçu/Bragança/PA. São destacadas as maneiras como a divisão sexual do trabalho e o acesso ao trabalho remunerado, sobretudo o beneficiamento do caranguejo, atualizam a persistência sócio-histórica das desigualdades de gênero. Interessa salientar que a reflexão desta estabilidade se apoia nas mudanças que vêm se dando nas relações entre homens e mulheres: construção de flexibilidades estratégicas no sentido de recriação de práticas e de valores que, simultaneamente, mantêm o sistema de gênero. Identifica-se a inflexibilidade das representações sociais hierárquicas e assimétricas de gênero ancoradas na capacidade reprodutiva das mulheres.

Palavras-chave: Relações de gênero, relações de trabalho, populações tradicionais, extrativismo, pesca artesanal.

\section{SEXUAL DIVISION OF LABOR AND GENDER RELATIONS IN THE ESTUARINE AND COASTAL AMAZON REGION}

\begin{abstract}
The article discusses the results of research conducted by the SocioEnvironmental Studies Coastal Group of the Federal University of Pará, Brazil - UFPA in various communities of traditional populations in the region of the Marine Extractive Reserve Caeté Taperaçu-Bragança-PA. It highlights how the sexual division of labor and access to paid work, in particular the treatment of crabs, works to update the socio-historical persistence of gender inequalities. Interesting enough, the reflection of this stability is based on the changes that have operated on the relations between men and women: the construction of strategic flexibilities in the sense of rebuilding of practices and values that, simultaneously, maintain the gender system. The inflexibility of the hierarchical and socially asymmetrical representations are anchored in the reproductive capacity of women.
\end{abstract}

Keywords: Gender relations; work relations; extractivism; traditional populations; artisanal fishing. 


\section{DIVISIÓN SEXUAL DEL TRABAJO Y RELACIONES DE GÉNERO EN EL CONTEXTO DEL ESTUARIO-LITORAL AMAZÓNICO}

\section{Resumen}

$\mathrm{El}$ artículo discute resultados de las investigaciones que se llevan a cabo de manera coordinada por el grupo de investigación Estudios Socioambientales Costeros / UFPA, en varias comunidades de poblaciones tradicionales, en la región de la Reserva Extractiva Marina de Caeté-Taperaçu/Bragança/PA. Se destacan las formas por las cuales la división sexual del trabajo y el acceso al trabajo remunerado, especialmente el procesamiento de cangrejo, actualizan la persistencia sociohistórica de las desigualdades de género. Interesa salientar que la reflexión de esta estabilidad se basa en los cambios que se están recibiendo las relaciones entre hombres y mujeres: construcción de las flexibilidades estratégicas hacia la recreación de las prácticas, de los valores que mantienen al mismo tiempo el sistema de género. Además se identifica la inflexibilidad de las representaciones sociales, jerárquicas y asimétricas de género ancladas en la capacidad reproductiva de las mujeres.

Palabras-clave: Relaciones de género; relaciones de trabajo; poblaciones tradicionales; extractivismo; pesca artesanal.

Endereço da primeira autora para correspondência: Universidade Federal do Pará - Campus de Bragança, Alameda Leandro Ribeiro - CEP: 68600000, Aldeia, Bragança - PA. E-mail: normacosta@ufpa.br 


\section{INTRODUÇÃO}

O texto apresenta algumas considerações fruto da reflexão das autoras e de resultados de atividades coletivas desenvolvidas pelo grupo de pesquisa Estudos Socioambientais Costeiros, do Programa de Pós-Graduação em Biologia Ambiental do IECOS - Instituto de Estudos Costeiros da Universidade Federal do Pará, campus Bragança, com apoio da Capes e do $\mathrm{CNPq}$, em que vem se desenvolvendo o projeto de pesquisa "guarda-chuva" Gênero e conservação da biodiversidade: a Reserva Extrativista de Caeté-Taperaçú/ Amazônia Paraense, coordenado por Deis Siqueira. ${ }^{1}$

Trata-se, simultaneamente, de avanços em torno de resultados de investigações realizadas para a elaboração de trabalhos finais de Pós-Graduação de três das autoras, a saber: Marcella Ever, O lugar da mulher na apropriação e uso dos recursos naturais e nas atividades produtivas em Caratateua, Bragança, Pará, Brasil, dissertação defendida e aprovada em 2012 (Ever 2012); Maria Gomes, cuja dissertação trata das relações de gênero na catação do caranguejo na comunidade do Treme, a ser defendida em 2013; e Norma Vieira, cuja tese discute a pesca artesanal, articulando gênero, saberes e geração na Vila do Bonifácio, em desenvolvimento. ${ }^{2}$ Todos são articulados pelo citado projeto sobre gênero. Os dados estão sendo coletados desde 2011.

Os procedimentos metodológicos utilizados encontram-se detalhados nos trabalhos e no referido projeto de pesquisa. As autoras participaram em várias das atividades que se desenvolvem nas comunidades, pois com este procedimento acredita-se poder minimizar dissimetrias inerentes às entrevistas, assim como controlar, de alguma maneira, os efeitos da violência simbólica da relação pesquisador (a)-informante (Bourdieu 1997a). Para a coleta de dados foram utilizados questionários, entrevistas semidirigidas, grupos focais e associações livres. No Treme, foram aplicados 163 questionários e realizadas 13 entrevistas, incluindo-se uma idosa que não trabalhou na catação do caranguejo. Em Caratateua, foram realizadas 119 entrevistas e 25 na Vila do Bonifácio.

As falas gravadas e transcritas foram lidas como ingredientes, matérias-primas, elementos significativos das representações sociais do coletivo, visto que se concorda com Jodelet (2001) de que estas representações são uma forma de conhecimento elaborada socialmente e partilhada entre as pessoas, que converge para a construção de uma realidade comum a um grupo social e possui um objetivo prático. Ou seja, as representações sociais são orientadas para a comunicação e igualmente uma forma comprometida e/ou negociada de explicar e interpretar a realidade, o contexto material, social e ideativo em que se vive (Jodelet 1985; 2001); são núcleos estruturantes do social e, simultaneamente, campos socialmente elaborados, estruturados (Moscovici 1988), permitindo desvendar redes de significados os quais sustentam o cotidiano, que criam o social e sem os quais nenhuma sociedade existe.

A escolha dos participantes da pesquisa contou com várias estratégias, desta- 
cando-se a representatividade geográfica (residências) e a técnica de bola de neve ${ }^{3}$ (os e as primeiras entrevistadas indicaram outras e outros informantes).

As reflexões incluem pesquisas realizadas em outras comunidades da região costeiro-estuarina de Bragança, mas aqui serão enfatizadas três delas, a saber: Vila dos Pescadores, Caratateua e Treme. Na primeira, a atividade principal é a pesca em águas costeiras. ${ }^{4}$ Nas outras duas, também se pesca, mas na atualidade a principal ocupação é a coleta e o beneficiamento de caranguejo (Ucides cordatus), sendo que, no Treme, este processo encontra-se mais avançado, ou seja, proporcionalmente ocupa mais pessoas do que aquele, e o problema dos resíduos é mais evidente, assim como a divisão do trabalho é mais especializada. Em Caratateua, são mais comuns os casos em que uma mesma família coleta, prepara e cata o caranguejo em uma mesma casa. Ao homem cabe a coleta e os primeiros tratamentos do caranguejo; à mulher, o colhimento de sua carne ("massa"). O processo destes fazeres traz embutido uma complexa organização da divisão social e sexual do trabalho (Hirata \& Kergoat 2007).

Para se chegar ao produto final, isto é, à massa de caranguejo, passa-se por três etapas bem definidas. A primeira refere-se à coleta dos animais e é realizada por homens, os quais, de acordo com as marés (pois só entram no mangue na maré baixa), deslocam-se sempre em grupo, normalmente em pequenos barcos, sendo, no entanto, a retirada dos animais, de um a um, um ato individual, de forma relativamente isolada em uma determinada área. Os caranguejos ficam enterrados no tijuco (areia de lama mesclada com resquícios de matéria orgânica, sedimento comum do ecossistema de manguezal), em tocas de aproximadamente um metro e meio de profundidade (Oliveira 2013).

A segunda fase caracteriza-se pelos primeiros tratamentos dos animais, os quais consistem em sua matança, esquartejamento e cozimento, para que, ensacados e pesados, sejam distribuídos nas residências das catadoras. É também um trabalho atribuído aos homens, sobretudo no Treme.

A terceira fase consta da retirada da carne do caranguejo, que é ensacada em embalagens de meio ou um quilo. Este trabalho, o da catação, é realizado por mulheres, em seus domicílios. O produto final é recolhido, na hora acordada, pelos mesmos homens designados pelo patrão que entregaram os animais. No caso de Caratateua, onde a divisão do trabalho é menos especializada, quem o recolhe é o marreteiro.

Realizava-se a agricultura com maior intensidade em todas as comunidades da região. Essa prática veio perdendo importância, inclusive devido à menor disponibilidade de terras, com o crescimento do espaço ocupado pelas residências. $\mathrm{Na}$ Vila de Bonifácio, ela nunca foi importante pelas características físicas do solo (típico de áreas costeiras: planície arenosa, dunas, pântanos salinos). Mas, a agricultura ainda guarda maior importância em Caratateua, se comparada com a do Treme, porque nesta última, as mulheres se deslocaram, com maior 
força, da agricultura para o beneficiamento do caranguejo. Daí se identificar, também, maior dependência na compra de produtos alimentícios nos pequenos comércios ("baiucas") existentes, ainda que tenha sido introduzida, em Caratateua, a primeira casa de catação na região do manguezal de Bragança, em 1977 (na época, o Treme era parte do Distrito de Caratateua) (Blandtt 2000).

De qualquer maneira, trata-se de comunidades de populações tradicionais, com características bastante similares, sendo a pesca sua principal atividade. Como não é o momento de se adentrar na discussão em torno do conceito, consideram-se povos e comunidades tradicionais os grupos culturalmente diferenciados e que se reconhecem como tais, que possuem formas próprias de organização social, e que ocupam e usam territórios e recursos naturais como condição para sua reprodução cultural, social, religiosa, ancestral e econômica, utilizando conhecimentos, inovações e práticas gerados e transmitidos pela tradição, tal como definida pela PNPCT - Política Nacional de Desenvolvimento Sustentável dos Povos e Comunidades Tradicionais (Brasil 2007).

Concordando com Diegues (1995), comunidades rurais situadas à margem dos estuários podem ser consideradas como civilizações do mangue: sua vida econômica, social, cultural encontra-se estreitamente ligada à flora e à fauna do mangue, aos ciclos lunares, sazonais e de maré, aos períodos de reprodução dos animais.
$\mathrm{Na}$ região, prevalecem os arranjos artesanais. As poucas tecnologias artesanais utilizadas, por exemplo, para a pesca do caranguejo (luvas, sapatos, gancho) são criadas e confeccionadas por elas e eles mesmos. Identifica-se a centralidade da dimensão subjetiva do trabalho em que o saber-fazer do trabalhador e da trabalhadora e sua destreza no manejo dos instrumentos que utilizam são base para o processo de trabalho.

O objetivo inicial do grupo era identificar o mundo dos homens e o mundo das mulheres nas comunidades da região. Afinal, tratam-se de comunidades que funcionam com práticas, valores, normas, muito distintos daqueles da modernidade, em que são hegemônicas as relações indivíduos e Estado. A estrutura de gênero é diferente daquela que prevalece na sociedade ocidental urbana, moderna, da qual partem as interpelações hegemônicas (acadêmicas, estatais).

Pressupondo que o gênero estrutura todos os campos no contexto específico da região (comunitário, extrativista), buscávamos os coletivos, os domínios, os tecidos próprios das relações, de e entre os segmentos de gênero. Isto porque as comunidades tradicionais são, por excelência, divididas nestes dois grupos, com sua distribuição de direitos e de deveres, suas formas próprias de convivência, seus sistemas de autoridade, sua malha institucional interna. Espaços sociais ou mundos de gênero, com seus respectivos coletivos, internamente estruturados (Segato 2005: 05).

Porém, no processo de discussão, a divisão sexual do trabalho se impôs en- 
quanto problemática. A partir dela, a reflexão retomou, inevitavelmente, as relações de gênero e o gendramento da vida, os quais nos permitiram deslizar analiticamente entre a perplexidade inicial diante da existência de mundos de homens e de mulheres; o trânsito entre eles e o simultâneo reconhecimento da existência de um mundo dos homens e um mundo das mulheres: variantes e invariantes nas estratégias de produção e de reprodução, de criação e de recriação de relações sociais gendradas. Assim, avançamos no entendimento da divisão sexual do trabalho existente nas comunidades e na região.

\section{CONTEXTUALIZAÇÃO}

\section{REGIÃO ESTUARINO-COSTEIRA DE BRAGANÇA/PARÁ}

A plataforma continental da Região Norte do Brasil possui uma área de aproximadamente $295.000 \mathrm{~km}^{2}$. Desta área total, $55.0 \%$ fazem parte do Estado do Pará. Zona costeira é uma região compreendida entre ambientes continentais e marinhos. Estes últimos são produtos de processos de interação complexa que estão constantemente modificando rochas e sedimentos, são importantes como hábitat crítico para uma infinidade de espécies e alimentam uma grande quantidade de processos ecológicos (Souza-Filho \& ElRobrini 2000).

Os manguezais, um dos mais importantes ecossistemas da costa brasileira, são um tipo específico de floresta tropical ou subtropical úmida; ecossistemas em transição entre o continente e o mar, formados nas áreas dos estuários e desembocaduras dos rios, com variações constantes de inundações. São, ainda, bacias hidrográficas entre águas doces, salobras e salinas que compõem áreas privilegiadas para processos e reservas ecológicas, berçários, meios nutritivos e locais de multiplicação de numerosas espécies animais e vegetais. Fornecem bens e serviços singulares para o desenvolvimento dos estuários e das formações associadas, tais como os ecossistemas da plataforma continental contígua. Entre as principais contribuições, destacam-se: a estabilização da linha de costa e proteção contra tsunamis e outros fenômenos meteorológicos; alta taxa de sequestro de carbono da atmosfera; e aprovisionamento de áreas berçários para espécies marinhas, limícolas, dulcícolas, pelágicas e recifais.

A costa paraense é caracterizada pela presença de um elevado número de estuários ${ }^{5}$ que possuem grande influência na dinâmica dos fatores físicos e oceanográficos e na ecologia da biota da região (Camargo \& Isaac 2003). Dentro deste contexto, encontra-se a planície costeira bragantina, que abrange desde a ponta do Maiaú até a foz do rio Caeté, com aproximadamente $40 \mathrm{~km}$ de extensão. Esta planície se caracteriza por penínsulas cortadas por canais-de-maré que ligam o manguezal aos estuários dos rios Caeté e Taperaçu (Souza Filho \& Paradella 2002).

O município de Bragança localiza-se na chamada região do Salgado ou leste paraense e o seu manguezal caracterizase por uma grande diversidade de ecos- 
sistemas: praias, baías, costões, manguezais, restingas, ilhas, recifes, falésias, estuários, brejos.

De acordo com Krause et al. (2001), aproximadamente $90 \%$ da península bragantina (cerca de $120 \mathrm{Km}^{2}$ ) são cobertos, fundamentalmente, por três espécies de mangue (plantas nativas de áreas de manguezal): mangue vermelho [Rhizophora mangle L.], Siriúba [Avicennia germinans(L.) Stearn] e mangue branco [Laguncularia racemosa (L.) Gaertn f.], sendo a primeira a espécie dominante (Marques et al. 1997; Proisy et al. 2003). Os bosques de mangue são bem desenvolvidos, com árvores de até 25 metros de altura, e entrecortados por pequenos canais que permitem a entrada de nutrientes provenientes das águas da baía do Caeté (Wolf et al. 2000).

\section{RESERVA EXTRATIVISTA}

Por ser considerada uma das principais áreas de risco da Costa Atlântica e alvo das reivindicações da população organizada local, em 2005 foi criada, no município de Bragança, a Reserva Extrativista Marinha de Caeté-Taperaçú (RESEX) (Figura 1), com uma extensão territorial de $420 \mathrm{~km}^{2}$, compreendendo quase toda a Península de Ajuruteua e englobando os mais distintos ecossistemas (mangue, terra-firme, rios, várzea, estuários, campos salinos etc.) (Brasil 2005).

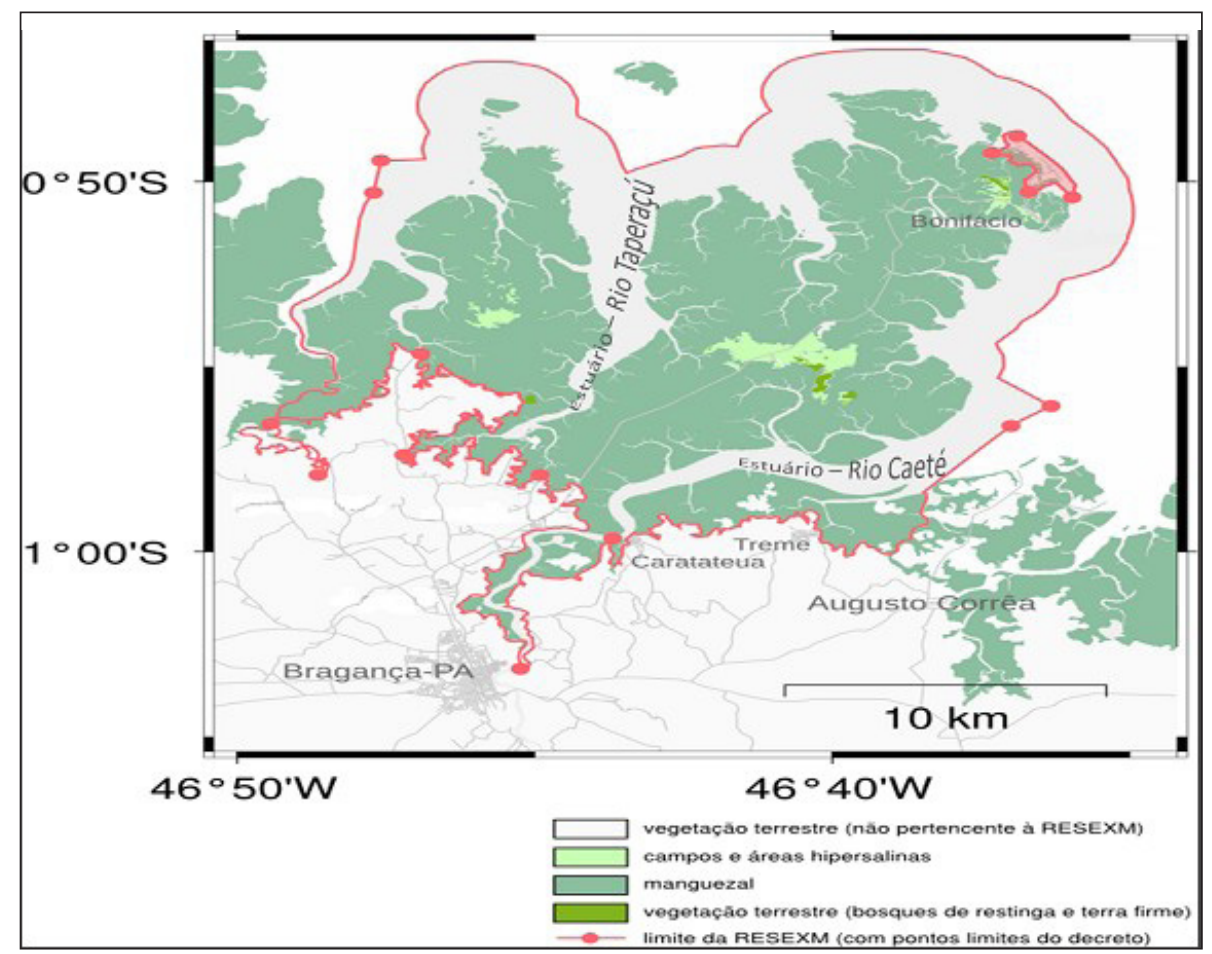

Figura 1 - Mapa da Reserva Extrativista Marinha de Caeté-Taperaçu, com destaque para as comunidades de Bonifácio, Caratateua e Treme (Imagem editada por Ulf Mehlig, UFPA/PPBA em 2013). 
As RESEXs são Unidades de Conservação da Natureza (UC), que têm como principal objetivo a conservação da biodiversidade (uso dos recursos com garantia de seu usufruto no futuro), apoiando os povos e comunidades tradicionais/extrativistas que nelas vivem e que mantêm relações próximas com os ecossistemas e os recursos naturais existentes na região. Tratase de áreas de domínio público com uso concedido àquelas populações. As Reservas Extrativistas Marinhas são uma subcategoria das Reservas Extrativistas. Segundo o Artigo 18 do Sistema Nacional de Unidades de Conservação da Natureza (Brasil 2000), elas são uma: "Área utilizada por populações extrativistas tradicionais, cuja subsistência baseia-se no extrativismo e, complementarmente, na agricultura de subsistência e na criação de animais de pequeno porte, e tem como objetivos básicos proteger os meios de vida e a cultura dessas populações, e assegurar o uso sustentável dos recursos naturais da unidade" (Brasil 2000).

As comunidades que compõem a Reserva de Caeté-Taperaçú caracterizam-se por uma grande diversidade ambiental e de atividades, sobretudo extrativistas. Dá-se um uso intensivo dos recursos costeiros, como pesca de espécies variadas, a saber: mariscos variados, camarão (Litopenaeus schmitti), Gó (Macrodon ancylodon), sardinha (Anchovia clupeoides), turu (Teredo sp.), siri (Calinectes sp.), sururu (Mytella sp.), caranguejo (Ucides cordatus) e outros recursos do manguezal ainda que em menor escala: Ostra (Crassostrea rhizophorge) e sarnambi (Lucina pectinata).
Ademais, coleta de mel e agricultura familiar por meio do cultivo de mandioca, milho, feijão, arroz, laranja, entre outros (Gorayeb 2008).

\section{TEMPO SOCIAL E TEMPO DA NATUREZA}

Por um lado, ainda não se operou a revolução típica das sociedades urbano-industriais em torno do arranjo da relação trabalhador/instrumento/objeto, porque as pessoas, mediante instrumentos e tecnologias simples, com seu trabalho vivo atuam e modificam os objetos, imprimindo-lhes sua ação, sua criatividade, sua vontade. Saber-fazer e destreza no manejo dos instrumentos são bases para o processo de trabalho.

Populações tradicionais, artesanais, extrativistas, organizadas em comunidades onde o tempo social e a vida cotidiana são fortemente regidos pelos ciclos naturais; o tempo da natureza impõe suas regras de forma significativa. As atividades desenvolvidas nos vários ambientes desta zona costeira são comandadas, em boa medida, pela dinâmica natural dos diversos recursos biológicos encontrados nestes ecossistemas. Ainda são bastante presentes as forças da natureza sobre a vida social, como é o caso do movimento das dunas, redesenhando territórios e movendo residências. Assim, essas populações têm sua vida econômica, social e cultural intimamente ligada à flora e à fauna, aos ciclos lunares, sazonais e de marés, à observação da alternância do dia e da noite, das estações do ano, dos tempos de re- 
produção dos peixes e muitos outros animais provenientes dos mangues, das marés e da pequena agricultura (Glaser e Oliveira 2005). Comparando-se esta realidade com a do tempo assalariado, ainda se identifica grande plasticidade nas relações entre as determinações externas e os limites biopsicossociais das pessoas no processo produtivo. $\mathrm{E}$ as forças da natureza fazem parte das representações sociais, do imaginário social, daí o poder das religiões e da religiosidade, como indicaram Durkheim (2008) e Weber (1967) ao pensarem as sociedades pré-capitalistas.

Ainda, as referências sobre as práticas de solidariedade, de ajuda mútua, de escambo, de pagamento do trabalho via distribuição do "quinhão" (participação do trabalho paga com parte do recurso natural conseguido coletivamente) são muitas e atualizadas (Almeida 2002). Ao pensarmos parentesco ou sistemas de parentesco, estamos nos referindo à família, porque famílias nucleares sempre estão inseridas em práticas de solidariedade familiar, ou seja, formas de colaboração entre todos os membros, relacionando-se diretamente com a organização da comunidade, a qual é fortemente marcada por laços de parentesco mais distantes, e que forma uma rede sempre reatualizada e reaproximada pelos casamentos. O parentesco é um princípio organizativo fundamental e elemento central da reprodução social. As relações sociais são comunitárias, ou seja, se ancoram em um sentimento subjetivo por parte dos membros de pertencer afetiva e tradicionalmente ao mesmo grupo (Weber 1994).
Sabe-se que um dos principais mecanismos do processo de mercantilização geral operado pelo capitalismo se dá pela expulsão de camponeses e populações tradicionais de suas terras, alimentando a formação de um mercado de trabalhadores livres para o capital. Outro mecanismo, simultâneo, é a apropriação privada dos elementos da natureza. Ao contrário, em lugar de expulsar, a região tem funcionado como território relativamente livre de recepção de agricultores expulsos de outras regiões, sobretudo do próprio nordeste do Estado do Pará (Furtado 1987; Maneschy 1995a).

Ademais, no que diz respeito à territorialidade dessas comunidades, a ocupação da terra não é feita em termos de lotes individuais, predominando seu uso comum. A utilização dessas áreas obedece, sobretudo, à sazonalidade das atividades (agrícolas, extrativistas ou outras), caracterizando diferentes formas de uso e ocupação dos elementos essenciais ao ecossistema, em que se tomam por base laços de parentesco, compadrio, vizinhança. Além das águas doces e salgadas, é comum o uso coletivo de muitas áreas terrestres.

\section{MONETARIZAÇÃO, MERCANTILIZAÇÃO, GERAÇÃO DE RENDA}

A região encontra-se dentro do movimento de expansão e de consolidação do capitalismo, no qual se destaca a crescente mercantilização da vida social, em que o mercado vai passando paulatinamente de ordem secundária para ordem central, mesmo que as in- 
dústrias e o trabalho assalariado estejam distantes geograficamente e longe de se tornarem hegemônicos na região. Assim, a vida vem se monetarizando crescentemente nas comunidades estudadas, e as pressões no sentido de se conseguir renda monetária também se intensificam.

Os principais produtos comercializados e que geram renda além de arranjos participativos remunerados dos homens com os chamados patrões (financiadores das atividades, em geral, donos dos barcos motorizados ou não), são a pesca artesanal e a coleta de caranguejo. Outros produtos, tais como o sururu e o mexilhão, também são comercializados, mas são usados, sobretudo, para o consumo do grupo doméstico.

Historicamente, o peixe foi o principal produto destinado à venda. Com as alterações tecnológicas e a modernização dos equipamentos ocorridas nas últimas décadas do século passado, foram sendo gestadas dificuldades para a manutenção do trabalho autônomo dos pescadores artesanais (Maneschy 1995). Assim, por um lado, a coleta do caranguejo vendido vivo foi se tornando a principal fonte de renda para muitos homens; por outro, uma maior dependência do mercado, impulsionando a busca de ganho monetário e o fortalecimento da importância da produção direta para autoconsumo, como a coleta de mariscos, a cata de lenha nos bosques e florestas de mangue, a criação de pequenos animais e a pequena agricultura.

A partir da década de 1980, o beneficiamento do caranguejo, atividade voltada, sobretudo, ao autoconsumo do grupo doméstico, como a maioria dos demais recursos naturais, passou a ser a principal fonte de renda para as mulheres em Caratateua e no Treme.

\section{DIVISÃO SEXUAL DO TRABALHO}

Homens e mulheres compõem dois grupos sociais envolvidos em relações específicas, as relações sociais de sexo. Segundo Kergoat (2009), assim como as demais relações sociais, as de sexo ancoram em uma base material, o trabalho, e revelam-se através da divisão social do trabalho entre os sexos, denominada divisão sexual do trabalho.

De fato, parece ser muito antigo o padrão de divisão sexual do trabalho no sentido de excluir as mulheres da pesca de mar, exclusão ancorada em várias interdições no plano simbólico e diversos mecanismos de controle sobre elas (Maués 1993; 1994). Mas, na região há muitas notícias de que mulheres pescam em águas próximas à terra (pesca de beira ou de mar raso), com armadilhas fixas ou móveis. Nunca deixaram de pescar em rios, lagos, manguezais, praias (Maneschy 1995b). Ademais, há também o seu trabalho gratuito na elaboração, manutenção, reposição de equipamentos de pesca (como tecer e consertar redes), ou seja, o de garantirem condições de forma contínua para a realização da pesca.

De qualquer forma, atividades desenvolvidas por mulheres, mesmo que idênticas àquelas feitas por homens, não são consideradas trabalho, e sim ajuda, confirmando inúmeros estudos 
existentes em torno de agricultores familiares e populações tradicionais (artesãos, extrativistas, pescadores artesanais), os quais indicam uma divisão sexual bem definida, a inexistência de ou pouco intercâmbio de tarefas e obrigações, o prestígio masculino, a invisibilidade do trabalho da mulher (Paulilo \& Brumer 2004; Scott \& Cordeiro 2007; Di Ciommo 2007). Entre os estudos realizados na região podem ser indicados: Santos (1992); Maneschy (1993; 1994; 1995a, 1995b); Maneschy \& Escallier (2002); Henrique (2005); e Maués (1993; 1994). Almeida (2002), referindo-se especificamente ao nordeste do Pará, afirma que a mulher assume, em geral, uma sobrecarga de funções sem a correspondente visibilidade ou reconhecimento social de sua importância na lógica da produção.

Historicamente, "o mar é do homem, o peixe é da mulher", como indica o dito popular. Ou seja, o homem pesca, a mulher cuida do pescado, além da domesticidade: cuidar da casa, dos filhos, do quintal, da pequena agropecuária e da extração de muitos produtos para o grupo. Isto é, encarrega-se da "produção do viver" (Hirata \& Kergoat 2007: 596), ou do trabalho para a chamada reprodução social (Dedecca 2004). Trabalho doméstico é aqui entendido como um conjunto de tarefas relacionadas ao cuidado dos membros da família e que são executadas no contexto do lar, ou seja, em domicílio conjugal e parentela; trabalho gratuito realizado essencialmente por mulheres.

Desse modo, o campo do cuidado tem sido priorizado para as mulheres. É uma prática social que limita o espaço de sua atuação na pesca e nas atividades extradomésticas, assim como a visibilidade da mulher enquanto pescadora ou trabalhadora. As atividades de pesca desenvolvidas por elas nas várias comunidades são lidas, representadas, como extensão das atividades ligadas ao cuidar. Nesses contextos, como em muitos outros, as mulheres estão inseridas no campo do cuidado da casa e da família, e suas atividades de pesca, coleta, apanhar lenha, ocorrem em consonância, como se fossem uma extensão destas atribuições assim como o quintal é representando como uma extensão da casa.

Ao contrário do que é considerado como esfera econômica, mercado, mundo das mercadorias, o trabalho doméstico se efetiva em torno de relações entre pessoas e ancora-se em uma disponibilidade permanente do tempo das mulheres a serviço da família (Fougeyrollas-Schwebel 2009). Neste sentido, concordando-se com Delphy (2009), o trabalho doméstico determina a condição das mulheres nas comunidades estudadas. Ainda segundo esta autora, a família pode ser lida também enquanto um local de exploração econômica das mulheres, pois, nela, dá-se uma apropriação material pelos homens de sua força de trabalho, sejam elas esposas, mães, filhas.

Ainda, assentindo-se com a literatura específica, a divisão sexual do trabalho, mesmo que varie de sociedade para sociedade, porque é historicamente adaptável, tem dois princípios organizativos: a) o da separação (há trabalhos de 
homens e trabalho de mulheres); e b) o hierárquico (maior valor ao trabalho dos homens, ou o trabalho de um homem vale mais do que o trabalho de uma mulher).

$\mathrm{Na}$ região em pauta, até as últimas décadas do século passado, diante da inexistência do gelo, os peixes, para a venda ou para o autoconsumo, eram limpos, salgados e secos. Este era um trabalho em que a família funcionava como uma unidade técnica de produção familiar integrada (pré e pós-captura), do qual participavam mulheres, crianças e idosos, sendo o papel das primeiras fundamental e centralizador das atividades. Com o surgimento do gelo e as inovações tecnológicas introduzidas na pesca, deram-se mudanças importantes na divisão sexual do trabalho em torno das atividades rotineiras de conservação dos instrumentos de pesca. A família já não tem que salgar o pescado e a presença da mulher na atividade pesqueira tornou-se ainda mais invisível.

Por sua vez, a catação de caranguejo, antes uma atividade para o autoconsumo e, portanto, de mulheres, também passou por uma nova divisão de trabalho. Os homens passaram a se encarregar da primeira etapa (limpar, esquartejar, cozinhar); as mulheres, a extrair a carne do animal, inicialmente concentradas, por alguns comerciantes do produto, em algumas casas (casas de catação). Aos poucos, esta atividade de extração da carne foi retornando às residências das mulheres; e a primeira etapa do processo continuou sendo realizada por homens e em alguns locais destinados a estas atividades. Confir- mou-se que, em situações de dificuldades (diminuição da pesca; predação marinha; introdução de tecnologias competidoras com a pesca artesanal), o trabalho remunerado da mulher passa a ser essencial para a manutenção do grupo doméstico, mas ainda assim esta inserção não é acompanhada de visibilização e de valoração. No mundo das atividades pesqueiras, como lembra Woortmann (1992), o universo masculino relega ao silêncio o universo feminino, mesmo quando as atividades das mulheres são cruciais para a reprodução social do grupo como um todo. Isto porque as relações de gênero, logo, a relação entre homens e mulheres são estruturantes, assimétricas e hierárquicas. Tanto assim, que a maioria das mulheres catadoras não se considera chefes de família. Apenas assim se identificam quando na residência não há a presença masculina. Se houver, o homem será considerado o chefe. Porque se trata de uma relação de poder dos homens sobre as mulheres. Afinal... "A ideia de uma complementaridade entre os sexos está inserida na tradição funcionalista da complementaridade de papéis" (Hirata \& Kergoat 2007: 603).

Portanto, a divisão sexual do trabalho tem o valor de um conceito analítico, pois:

"é a forma de divisão do trabalho social decorrente das relações sociais de sexo (...) Tem por características a destinação prioritária dos homens à esfera produtiva e das mulheres à esfera reprodutiva e, simultaneamente, a ocupação pelos homens das funções de forte valor agregado" (Kergoat 2009: 67). 
Confirmando a literatura específica, cabe às mulheres das comunidades pesquisadas uma multiplicidade de atividades domésticas e extradomésticas. No processo de beneficiamento do caranguejo, a ocupação do homem encerra-se à cada etapa, isto é, os coletores, embora dependam do tempo da maré para entrar no manguezal, ao retornarem e entregarem os animais ao patrão, concluem seu trabalho daquele dia. O mesmo acontece com a equipe envolvida com a primeira etapa do tratamento do caranguejo. Depende da chegada dos coletores para começar o trabalho, mas, ao concluí-lo, dá por encerrada sua tarefa.

De maneira distinta, a ocupação da mulher se divide em múltiplas atividades, pois, além da retirada da massa do caranguejo, é responsável por todos os afazeres domésticos. Um dia de trabalho de uma catadora inicia-se ainda de madrugada, por volta das 3 ou 4 horas, dependendo do momento da entrega do caranguejo. Trabalha até mais ou menos às 6 horas, quando faz uma parada para preparar o café e arrumar os filhos e filhas para a escola. Volta, então, para o trabalho até cerca de 9/10 horas, quando, em nova parada, sai para comprar algum produto para o preparo do almoço. Enquanto o almoço está cozendo, ela retorna para a catação. Cada familiar que chega vai se servindo e se alimentando. No geral, ela não para, pois o caranguejo deve estar catado e ensacado entre catorze e dezesseis horas, dependendo de sua agilidade e da quantidade de caranguejo que foi entregue.
No trabalho da catação, a mulher recebe ajuda dos familiares, dos maridos (maior no Treme do que em Caratateua) e dos filhos menores quando não estão na escola, além de outros parentes, inclusive dos idosos do grupo doméstico. Entretanto, essa ajuda se limita ao serviço da catação. Os ajudantes se veem desobrigados de outros fazeres quando este trabalho é concluído. Mas a mulher continua a trabalhar: é a vez das tarefas domésticas, incluindo limpeza da casa e seu entorno, afazeres que a mantêm ocupada até por volta de 21 horas, como afirma uma catadora do Treme:

"É difícil catar caranguejo. Colher a carne do caranguejo, é muito difícil, tem que ser rápida, para dar conta de catar e fazer as tarefas da casa, que ninguém faz, só a mulher, então tem que catar rápido, tirar toda a carne, não perder nada. É cansativo, é difícil. O homem trabalha, é dificil estar no mangal, mas depois, pronto, acaba. A mulher cata e quando termina, não acaba, continua a trabalhar" (Catadora de 49 anos).

Essa fala sugere que a dificuldade citada, quando se afirma que "é difícil catar caranguejo", talvez não se refira ao ato em si de catar, mas à dificuldade de se adequar ao tempo imposto pela responsabilidade do trabalho, o qual exige a entrega do produto num determinado horário.

Quando a catadora se refere à necessidade de "fazer as tarefas da casa, que ninguém faz, só a mulher”, parece indicar a divisão sexual do trabalho existente na comunidade, legitimada pelos invisíveis fios condutores das relações 
de subordinação da mulher, que a obriga ter, sem remuneração nem reconhecimento, dupla jornada de trabalho (Bruschini 2006; Hirata \& Kergoat 2007).

Observa-se, assim, que a ocupação da mulher é contínua e exige além da habilidade da catação, a de gerenciamento do tempo das tarefas que a ocupam. O seu tempo de catação (o patrão tem hora combinada para passar, ela "tem que ser rápida”) está relacionado ao tempo da natureza, ao tempo da relação de trabalho e ao tempo social imposto pela domesticidade, a qual lhe exige múltiplas responsabilidades, incluindo os cuidados dos idosos.

O seu tempo é marcado pela superposição de atividades enquanto o homem se centra em uma, no máximo duas atividades, como a pesca e a agricultura. $\mathrm{Ou}$ seja, identifica-se uma assimetria do uso de tempo entre os sexos. $\mathrm{E}$ as atividades domésticas estão ancoradas na normativa segundo a qual estas ocupações se assentam no afeto, longe da ideia de remuneração. $O$ mundo da casa é considerado de tal maneira que as famílias e, particularmente, as mulheres contam mais com a ajuda externa de outras mulheres do que com a dos cônjuges nos arranjos domésticos, nos casos de enfermidades e outras dificuldades (FougeyrollasSchwebel 2009). As tarefas domésticas dificilmente são compartilhadas com os homens, a não ser quando a mulher está enferma, segundo elas "no fundo da rede", ou seja, muito doentes. Ainda assim vale ressaltar que a participação de homens (maridos/companheiros e filhos) se limita a certas tarefas.
Nesse complexo de atividades (catação e afazeres domésticos), priorizar uma em detrimento da outra causa problemas. Se, em função de necessidades financeiras prementes ou por ser chefe de família, a mulher priorizar a catação do caranguejo em relação às atividades domésticas (não as realizando ou postergando-as), uma vez que, como afirmou a catadora acima, são atividades que "ninguém faz, só a mulher", ela será duramente criticada pela comunidade, sendo considerada "uma desleixada, que deixa a casa e os filhos a Deus dará", tal como afirmou uma idosa participante da pesquisa referindo-se a uma dona de casa, catadora, chefe de família e mãe de três filhos (de nove, sete e seis anos de idade). Na mesma entrevista, não foi destacada esta situação ou que, eventualmente, a catadora não seria tão rápida no trabalho, mas sim que ela não é uma boa dona de casa, que não está sabendo administrar o tempo da catação - a produção - com o tempo dos afazeres domésticos - a reprodução (Pinto 2003, 2010; Suárez 2000).

Ademais, o papel da mulher é fundamental na passagem dos Conhecimentos Ecológicos Locais (CEL) às novas gerações. E o valor destes conhecimentos, sobretudo na gestão de pescarias e de recursos marinhos, vem sendo crescentemente valorizado e investigado em diferentes ambientes biofísicos e em diversas partes do mundo (Diegues \& Arruda 2001; Huntington 2000).

Assim, confirmou-se, em boa medida, o que pesquisas das Ciências Sociais indicam, ou seja, que a maneira como homens e mulheres lidam com o meio 
ambiente é diferenciada. As mulheres têm um maior conhecimento e uma maior intimidade com as espécies, uma maior inter-relação com plantas medicinais e nutritivas e uma utilização mais racional e preservacionista dos recursos naturais. Porque, "em uma perspectiva transcultural, a mulher e seu mundo são geralmente percebidos como semanticamente afins com a terra e a natureza", suas atividades são de maior enraizamento no local do que as dos homens (Segato 2005: 6; Kuchemann 2000). Para as mulheres na região, faz parte do cuidar a lida com as plantas medicinais e a proteção à família dos perigos que apresentam seres sobre-humanos, tais como Mãe D’água e Curupira. ${ }^{6}$

Como se pode observar, foram identificados vários aspectos que nos encaminham a uma leitura das comunidades como muito similares, no que toca à divisão sexual do trabalho. Inclusive, porque são muito próximas em termos geográficos (a Vila do Bonifácio se distancia $35 \mathrm{~km}$ da sede do município de Bragança; Caratateua, a $18 \mathrm{~km}$ e Treme, a $15 \mathrm{~km}$ ) e socioambientais (sendo incluídas no entorno de uma mesma reserva extrativista). Entretanto, por detrás desta homogeneidade, encontram-se diferenças dignas de serem destacadas, as quais não logram ser explicadas apenas por uma leitura ancorada na divisão sexual do trabalho, nas diferenças sexuais. Afinal, atividades cotidianas podem indicar muito maior flexibilidade em relação à rigidez dos lugares atribuídos para homens e para mulheres, nas representações sociais existentes em torno da divisão sexual do trabalho. Sempre é bom lembrar que paradoxos ou ambiguidades para o olhar de quem pesquisa indicam, no geral "flexibilidade estratégica para os pesquisados" (Almeida 1986: 70).

\section{ALGUNS PARADOXOS DA DIVISÃO SEXUAL DO TRABALHO}

$\mathrm{Na}$ Vila do Bonifácio, o pescador reconhecido como tal pela comunidade é o homem porque vai ao mar. Quem vai regularmente ao manguezal é a mulher. Quando em terra, os homens constroem casas, fazem alguma carpintaria, atividades de manutenção do barco. Quando o homem vai para o mar ele deixa "a despesa da casa", ou seja, produtos não perecíveis, como farinha de mandioca, feijão, arroz, café, bolacha, leite. Cabe à mulher buscar, incluindo no mangue, os complementos diários da alimentação: turu, sururu, camarão, peixe, mexilhão. Também no mangal coleta madeira para produzir carvão e construir jiraus (bancadas elevadas de madeira usadas para lavação de utensílios domésticos e tratamento de alimentos, como peixes e aves).

No Treme e em Caratateua, o trabalho da coleta do caranguejo é do homem: é ele quem vai ao manguezal. No Treme, a coleta do sururu (coletado somente no manguezal, e não na água corrente - corrente de água estuarina) usado para autoconsumo é um momento de lazer eventual praticado por grupos de mulheres e de crianças e planejado com antecedência. Esta coleta é feita quase exclusivamente por mulheres e, 
fundamentalmente, para autoconsumo e com forte componente lúdico, ainda que elas aproveitem a oportunidade para também lavar roupa, estando sempre acompanhadas dos filhos e filhas. Apenas se dedicam à captura do sururu quando estão desocupadas, ou seja, não estão catando caranguejo, que é a atividade prioritária (geradora de renda financeira).

Em Caratateua, o sururu é retirado na corrente de maré, tem grande valor comercial e sua comercialização é importante também porque coincide com períodos de defeso do caranguejo (proibição de coleta). Durante o período de safra (dezembro a fevereiro, meses "secos" do ano, antes das "grandes chuvas"), é coletado por homens e por mulheres. Homens tiradores de caranguejo se deslocam para a coleta de sururu junto com as suas mulheres e familiares. A mulher participa, mas como ajudante do parceiro. Não há interdições para elas, ainda que se trate de uma prática difícil e arriscada, motivo que justifica a não ida delas ao mangue. Contudo, nos cuidados que seguem à captura, nas residências (cozer; peneirar ou catar; recatar - separar o molusco das valvas/ cascas), o trabalho é das mulheres. Fora deste período, como esta atividade é fundamentalmente para autoconsumo, é uma tarefa que cabe às mulheres.

Em Caratateua, a farinha de mandioca é produzida pela família e é bastante usual a criação de animais de pequeno porte. Esta última também o é no Treme, ainda que aqui não se fabrique mais farinha como há algumas décadas (decorrência do relativo abandono da agricultura). E na Vila do Bonifácio, há poucos animais de pequeno porte.

Assim, o mangue é "espaço de mulher" na Vila do Bonifácio, mas não o é em Caratateua e no Treme. Nestas duas comunidades, a principal atividade dos homens é coletar caranguejo; as mulheres dificilmente se atrevem a ir ao mangue, porque "se forem se perdem", além do trabalho ser "muito pesado e arriscado". Mas, na prática, elas se organizam para coletar turu e mexilhão no mangue, ainda que em áreas próximas da água (estuário). No caso do turu, inclusive, elas entram no manguezal onde também coletam sururu de dedo, o qual fica enterrado no tijuco e é puxado individualmente com o dedo na forma de gancho.

Afinal, o que é “do homem" e o que é "da mulher" nestas comunidades pesquisadas, nesta região ou nesta reserva extrativista? Como pensar, diante dos fatos indicados, a certeza de que a forma de divisão social do trabalho como tratada pela teoria seria "válida para todas as sociedades conhecidas, no tempo e no espaço"? (Kergoat 2009: 68).

Introduzindo o conceito de gênero e de relações de gênero. Até porque, à maneira de Scott (2009), partimos de que o termo gênero é útil, sobretudo, como pergunta. Não é um tratado programático nem metodológico. Tomamos a investigação, antes de tudo, como um convite para refletir criticamente o modo como se produzem, utilizam e transformam os significados dos corpos sexuados, porque, afinal, perguntas sobre gênero só podem ser formuladas e respondidas em contextos específicos, e a região estuarino-cos- 
teira amazônica é pouco estudada, sobretudo no que toca às questões de gênero.

\section{GÊNERO}

Partimos de que as relações de gênero são constitutivas, estruturantes de toda a vida humana, pois conformam o primeiro mapa cognitivo que organiza o campo social (valores, normas) e os comportamentos. São o primeiro organizador da vida social (marcas classificatórias e hierarquizantes), de todas as cenas sociais, todas as ações humanas, incluindo aqueles contextos em que convivem somente homens ou somente mulheres.

Portanto, gênero deve ser tomado como categoria analítica, não descritiva: construção social, cultural, psicológica que se impõe sobre as diferenças biológicas relacionadas ao sexo. Como se concebem as diferenças entre os sexos e quais são os efeitos dessa construção? Não se pode inscrever o corpo biológico como o terreno sobre o qual se constrói o gênero (Scott 2009). As diferenças entre sexo e gênero não são evidentes, mas é o gênero que traduz o sexo (Mathieu 2009).

Por que a centralidade da divisão sexual do trabalho dentro das construções de gênero? Segundo Ramos (2009: 03):

"a perspectiva de gênero supõe que a distribuição do trabalho não remunerado intradomiciliar é majoritariamente explicada pela forma como se estabelecem as relações de gênero a partir da divisão sexual do trabalho, a qual reserva ao homem o trabalho remunerado para o mer- cado (e também a participação na esfera pública de forma geral) e à mulher as atividades domésticas limitadas à esfera privada".

Ou seja, atribuição lida como destino de cuidar, a partir do lugar da maternidade, como fundamental, basilar para o estabelecimento das demais atividades e correspondentes valorizações e valorações hierarquizadas.

Tal como adiantado na introdução, não recortamos a divisão sexual do trabalho como objeto de pesquisa, mas durante o processo analítico esta se impôs. Isto porque, sobretudo, apresentou-se uma considerável diversidade de situações, de flexibilidades e de negociações entre homens e mulheres, adultos e crianças. Aparentemente, não se identificavam com clareza os termos de uma divisão sexual do trabalho tão basilar para o gênero.

E então poderíamos concluir, como o faz Ferrugem (2010), por uma divisão não sexuada do trabalho a partir de investigações realizadas em Novo Airão, na Amazônia, com artesãos de produção de arumã - fibra vegetal -, organizados em uma associação. A autora afirma "que a distribuição das tarefas, na produção do artesanato de arumã, não é pautada pela diferença sexual", mas pela "emergência das relações de parentesco flexibilizando a pressuposta divisão sexual do trabalho". Essa autora refere-se a estes pressupostos como uma "forma distorcida como os antropólogos recorrentemente leem as relações de trabalho, ou melhor, a distribuição do trabalho entre os membros da família, 
mais especificamente entre homens e mulheres" (Ferrugem 2010: 426, 438).

E, de acordo com inúmeros estudos já realizados, partíamos da centralidade da divisão sexual do trabalho no conjunto das relações assimétricas de poder existente entre homens e mulheres, ancoradas em uma série de elementos considerados como sendo "de homem" e "de mulher".

Assim, o esforço de reflexão chegou a alguns elementos chave para se tentar avançar na compreensão da problemática. Afinal, como exposto há pouco, a exposição de um dia de vida de uma catadora de caranguejo demonstrou o quanto as atividades gendradas do trabalho da catação do caranguejo se articulam ao gendramento do tempo. O homem, nas duas etapas do processo da catação, se permite, após o trabalho, ficar livre para dispor do tempo que tem como desejar, inclusive para ajudar a mulher na catação, mas, como afirmou a catadora, é a mulher que cata e, quando termina, continua a trabalhar (afazeres domésticos), o que indica que o tempo, mesmo quando as atividades são partilhadas na convivência cotidiana do lar, incluindo o trabalho de catação, não é o mesmo para o homem e para a mulher, assim como a valoração das tarefas.

A hierarquização e a correspondente valorização das atividades desenvolvidas nas várias comunidades têm como referência fundamental a existência de um gradiente entre autoconsumo do grupo doméstico e geração de renda, ou seja, um processo ancorado na monetarização dos resultados das atividades. Em que direção este gradiente se movimenta?
QUANTO MAIOR A RENDA GERADA

PELA ATIVIDADE, MAIOR SEU RECONHECIMENTO ENQUANTO TRABALHO, MAIOR VALOR E MAIOR INCLUSÃO NO DOMÍNIO MASCULINO

À medida que uma atividade ganha valor no mercado, ela tende a ser considerada do domínio masculino (e viceversa). Isto explica o fato de os homens estarem participando, crescentemente, da catação de caranguejo na comunidade do Treme, onde esta atividade já se atrelou ao mercado de forma muito mais nítida do que na comunidade vizinha de Caratateua.

Na Vila do Bonifácio, como os homens coletam peixes de espécies de maior valor comercial, esta atividade é principal e considerada masculina, à diferença das duas situações anteriores em que o caranguejo (coleta e catação) tem mais importância enquanto gerador de renda. Aqui, as atividades no manguezal, o qual é considerado uma extensão da casa, e a catação de caranguejo são da mulher. Suas atividades na pesca dos homens (confecção, conserto de redes) são consideradas ajuda, e as demais atividades desenvolvidas por elas são menos valorizadas e têm menor valor comercial. No jogo entre mercado e autoconsumo, as mulheres movem-se em direção às atividades de menor valor comercial, menor monetarização, menor valorização da atividade enquanto trabalho.

As atividades agrícolas servem como exemplo do gradiente em seu movimento inverso. Até a década de 1960, elas tinham um peso bem maior do que hoje na geração de renda, em re- 
lação ao caranguejo. Os homens, nelas, estavam bem mais engajados do que na atualidade: agora se tratam de atividades consideradas, em boa medida, complementares, voltadas, sobretudo, para o autoconsumo e, portanto, femininas. Ao passo que se movem os valores associados aos produtos (de mercado, monetários, geradores de renda), a atribuição das atividades também se move, porque o motor do movimento não é o sexo, é o gênero em seu movimento de conservação de relações de poder assimétricas.

\section{AS MUDANÇAS NA DIVISÃO SOCIAL DO TRABALHO JÁ NASCEM GENDRADAS}

Isto pode ser exemplificado pelo processo que vem ocorrendo no Treme, onde o processo de especialização do trabalho está mais avançado. Aqui os homens já se apropriaram, em boa medida, da primeira etapa da catação (limpar, esquartejar, cozinhar e embalar em sacos plásticos a carne dos caranguejos). Homens jovens e saudáveis estão preferindo esta tarefa à de coletar o caranguejo no mangue (porque aquela seria mais rentável, menos perigosa e menos cansativa), embora seja ainda, sobremaneira, desvalorizada, porque considerada como atividade de mulher. Mas, à medida que a demanda se incrementar, gerando maior renda monetária, pode-se hipotetizar que as mulheres, se não se organizarem, serão paulatinamente substituídas por homens também na extração da carne do animal, até porque maior demanda externa implicará maiores necessidades de subjugação do tempo de trabalho. Tanto que elas começaram a trabalhar em espaços coletivos na década de 1970 e voltaram para suas residências, enquanto que os homens, na primeira etapa da catação, trabalham em espaços a ela dedicados. Com maior monetarização, a atividade vai passando de "coisa de mulher" para "coisa de homem".

Ademais, é parte fundamental do movimento o fato de as mães se sentirem tensionadas entre as atividades remuneradas e as domésticas, entre a identidade de trabalhadora e a de mãe: "a ordem social é, antes de mais nada, um ritmo, um tempo". Conformar-se com a ordem social é primordialmente respeitar os ritmos, acompanhar a medida, não andar fora do tempo socialmente dado (Bourdieu 1979: 47).

O trabalho doméstico (útil ou produção do viver) é oposto à objetivação; ele é ligado às relações afetivas da família e baseado na disponibilidade materna e conjugal das mulheres (Hirata \& Zarifian 2009). Ou seja, são fundamentais os âmbitos psicológicos e a dimensão da afetividade na construção e consolidação da dominação (Hirata \& Kergoat 2007: 608).

Não é demais lembrar que a família é considerada como um princípio de construção da realidade social, uma categoria, a qual, simultaneamente, realiza descrição e prescrição. Não se visibiliza enquanto tal porque é quase universalmente aceita e admitida como dada (Bourdieu 1997b).

Em Caratateua, ainda não ocorreu uma divisão do trabalho tão clara como no 
Treme, e os homens podem "catar caranguejo" no caso de a mulher estar adoentada ou com alguma dificuldade. Trata-se de situações que não os desqualificam. Isto porque, em princípio, catar caranguejo é "coisa de velho, de homem doente ou de homem preguiçoso" e por ser uma atividade "de mulher", ou seja, é parte do domínio das mulheres, como também o era no Treme até há pouco tempo.

Note-se que originalmente toda a sequência, da limpeza até a extração da carne, era chamada de catação. Com o avanço da divisão sexual do trabalho, os homens são os encarregados da catação e as mulheres catam caranguejo (verbo). Catação, substantivada, diz respeito apenas à primeira etapa, a que é do domínio dos homens: ao nomear objetos, atos, seres, as pessoas os classificam. Afinal, "o léxico de uma língua natural constitui uma forma de registrar o conhecimento do universo" (Biderman 1998: 11).

\section{A ASSIMETRIA ESTRUTURANTE DO GÊNERO CONSTRÓI A DIVISÃO SEXUAL DE TRABALHO HIERARQUIZADA}

Este aspecto pode ser observado nas flexíveis valorizações do trabalho e em uma correspondente construção das identidades sociais. Em Caratateua, quanto mais solitária a mulher se dedica à atividade da catação, mais ela se identifica enquanto trabalhadora, com a identidade profissional de catadora. Por sua vez, as mulheres que coletam sururu, mesmo que para venda, porque, em geral, o fazem com os maridos, não se identificam enquanto tiradoras, mas como suas ajudantes, e o seu trabalho, como complemento, "bico", logo, não são pescadoras e, portanto, tampouco se identificam como marisqueiras, apenas têm a identidade de catadeiras. Como trabalham sem a companhia do parceiro, consideram-se catadeiras de caranguejo e de sururu.

Também na Vila do Bonifácio, quando a mulher vai com o marido para a pesca, considera-se sua ajudante. Ela também pesca peixes sem sua companhia, mas não se identifica como pescadora, apenas como marisqueira, porque realiza a atividade, geralmente, sem companhia de homens adultos. Na verdade, elas têm mais de uma prática profissional, porém o jogo destas identidades se dá na relação gendrada com as atividades desenvolvidas pelos homens, e pela presença ou não de homens adultos (maridos, irmãos, pais).

No Treme, elas se identificam, principalmente, como donas de casa. "Donas de casa que catam caranguejo". Daí que se deve pensar o trabalho em associação com a renda e, articuladamente, com o gênero. Mesmo que a renda da mulher no Treme ou em Caratateua seja maior do que a do marido, seu trabalho é considerado como complementar, assim como o são as atividades ligadas ao cuidar. Apesar de se tratar de renda monetária auferida pela catação, ela não está conseguindo valorizar seu trabalho e se valorizar, porque o olhar que a vê ainda a enxerga como dependente, complemento. De resto, elas sequer sabem explicar por que ganham tão pouco para um trabalho tão "sacrificoso". Situação 
esta que confirma a afirmação de Delphy (2009: 178):

"Rompendo com a oposição frequentemente asseverada entre produção mercantil e não mercantil, a exclusão do trabalho doméstico das mulheres do domínio econômico não decorre da natureza de sua produção. Com efeito, quando os mesmos bens são produzidos fora da familia, o trabalho que os produz é remunerado e, inversamente, $\mathrm{O}$ trabalho das mulheres permanece gratuito até mesmo quando sua produção é objeto de troca no mercado".

Ou seja, por um lado, a produção que é considerada como função, domínio, território, mundo masculino e por outro lado, a reprodução dos seres humanos tidos como função, domínio, território do feminino. $\mathrm{E}$ a divisão sexual do trabalho se reproduz e se reconstrói tanto na primeira quanto na segunda. Assim, as mulheres são consideradas mais aptas para a execução de tarefas minuciosas, porque têm dedos e movimentos ágeis e um corpo propício para a realização de tarefas repetitivas e que requerem longos períodos de tempo. No entanto, a produção social gendrada destas valorações pode ser confirmada pelo fato de como o trabalho para tarefas similares é caracterizado como leve ou pesado: pesado se realizado por homem e leve se executado por mulheres (Paulilo 1987). Nesta perspectiva, o valor social agregado nas atividades ligadas à pesca não está associado ao espaço de atuação e nem à modalidade de pesca, mas à hierarquização de gênero.

Por sua vez, também o território é gendrado. Na Vila do Bonifácio, não é proibido às mulheres entrar no mangue, o qual é representado, em boa medida, como parte ou extensão do quintal delas. Já nas outras comunidades, elas coletam no mangal para autoconsumo, mas entram e saem dele rapidamente ("há perigo de se perder") porque mangue é lugar de homem. Não é o espaço em si, mas, na medida em que a coleta do caranguejo passou a ser o trabalho-remuneração principal de homens, o mangue passa a ter marcas de interdição para mulheres. Não é o espaço geográfico, é de gênero articulado com renda construindo um território gendrado.

Portanto, uma observação não muito detida sobre uma cena familiar na catação de sururu, ou um homem costurando sua luva de capturar caranguejo poderia levar à conclusão, como o fez Ferrugem (2010), de que não haveria divisão sexual do trabalho, porque todos participam de todas as atividades e reina um clima de solidariedade, sem conflitos, entre os membros da família nuclear ou extensa. $\mathrm{O}$ ponto é que não se trata apenas de observar a divisão sexual de trabalho e menos ainda em uma atividade, e sim a complexidade dos domínios de homens e de mulheres, os quais são pautados pelas relações de gênero (masculino e feminino; o que é de homem, o que é de mulher) em redes complexas de articulação com demais dimensões, tais como geração, sazonalidade, mercado, território.

Relação social é, em princípio, uma tensão que atravessa o campo social. Essa tensão produz certos fenômenos sociais e, em torno do que neles 
está em jogo se constituem grupos com interesses antagônicos. Aqui se trata de grupos sociais de homens e de mulheres, que não podem ser confundidos com a dupla categorização biologizante machos-fêmeas. Estes grupos estão em constante tensão assentada, ainda que não exclusivamente, na divisão sexual do trabalho. Assim, as relações sociais de sexo e a divisão sexual do trabalho são expressões indissociáveis que, epistemologicamente, formam um sistema; a divisão sexual do trabalho tem o status de "enjeu" (o que está em jogo, em disputa) das relações sociais de sexo (Kergoat 2009: 71). Por detrás da "conciliação" há conflito, tensão, contradição, que caracterizam a incumbência simultânea de responsabilidades profissionais e familiares (Hirata \& Kergoat 2007:604).

Maneschy (1995b: 155) também indica que as mulheres não participam da pesca no mar e não se reconhecem como pescadoras. Mas alerta que uma observação mais atenta revela que elas não estão, de todo, ausentes desse domínio. Daí a justeza da recomendação de Alencar (1993) que indica a necessidade de o pesquisador considerar sempre as disparidades existentes entre o discurso dominante da comunidade, que distingue rigidamente as esferas de atividades de homens e de mulheres e o campo das práticas sociais.

Disparidades? O campo das práticas permite flexibilidades exatamente porque o campo dos valores, das representações sociais, está suficientemente firme em torno do que é de homem, mais valorizado, e o que é de mulher, menos valorizado. Esta hierarquia ancora-se, por sua vez, em: a) uma associação resistente, intransigente, do feminino com a maternidade e, logo, com a reprodução e com o cuidado; e b) atualização constante dos mecanismos de valorização das mudanças socioambientais, das novas práticas, de tal forma que o masculino ou o que "é de homem" siga mais valorizado do que aquilo que "é de mulher".

Porque, confirmando Mathieu (2009), o gênero se manifesta, materialmente, em duas áreas basilares: a) na divisão sociossexual do trabalho (e dos meios de produção); e b) no lugar que ocupa a procriação, a maternidade, na organização social do trabalho de procriação, em que as "competências reprodutivas" são exacerbadas por meio de diversas intervenções sociais.

\section{CONCLUSÕES}

O sistema de gênero conta com a divisão sexual de trabalho como uma das âncoras mais importantes, se não a mais importante, para produzir e reproduzir as relações de gênero e o gendramento da vida.

Atividades exercidas por mulheres e crianças e, eventualmente, idosos têm sido lidas como tendo um caráter marginal à atividade propriamente pesqueira, mas elas são funcionais, articuladas, essenciais para a prática da pesca artesanal em seu conjunto, sobretudo quando diminuem as capturas ou os preços do pescado. Isto porque a pesca do pescador se articula nas relações sociais, tarefas, responsabilidades familiares. 
As mulheres de pescadores, na busca por contribuírem para o orçamento doméstico, tentam suprir as necessidades básicas da família e, enquanto esposas, continuam a criar condições de reprodução da categoria. Mas, não se percebe a pesca em seu conjunto, em sua complexidade, em termos de homens e mulheres na pesca, com atribuições que não umas essenciais e outras complementares ou "ajuda".

Confirmando-se pesquisas realizadas em muitas partes do globo, há diferentes padrões e diferentes intensidades do uso de tempo, mas uma persistência de desigualdades de gênero. $\mathrm{O}$ tempo de trabalho remunerado, mais ligado ao mercado, tende a ser mais institucionalizado, mais regulado por normas, por acertos, por convenções. O tempo de trabalho não remunerado é também determinado, em boa medida, de forma aleatória, articulado com outros tempos definidos pela natureza ou por instituições (escolares, de transporte, de saúde), mas é menos sujeito a processos regulatórios externos. Porém, em geral, o tempo remunerado, o tempo econômico, tem precedência sobre o tempo dedicado à reprodução, às tarefas domésticas. De acordo com pesquisas realizadas em outros locais, no que toca à articulação dos usos do tempo para o trabalho econômico e o não remunerado: quanto mais tempo as mulheres se dedicam ao primeiro, menos tempo é alocado para as tarefas não remuneradas. Este aspecto ficou claro principalmente na comparação entre as comunidades de Caratateua e do Treme.
Apenas o trabalho remunerado é, em geral, considerado trabalho, e, quando exercido por mulheres, esta identificação é dificultada pela representação social hegemônica de que o que é de mulher é complemento, ajuda, de menor valor.

O olhar hegemônico, incluindo o de cientistas, e o das e dos fazedores de política pública, em sua maioria, enxerga de maneira acrítica a divisão sexual nas comunidades de pesca artesanal ou de outras populações tradicionais, na medida em que as atividades remuneradas ou ligadas a produtos comerciais são privilegiadas.

O fato de as mulheres terem de compatibilizar vários encargos domésticos e geração de renda, enfrentando o peso das concepções relativas aos lugares e papéis de gênero, concorre para excluílas do estatuto profissional de trabalhadoras da pesca (Maneschy, Siqueira \& Alvares 2012; Maneschy et al. 2012). Ou seja, confirma-se que, na divisão sexual do trabalho, as desigualdades são sistemáticas; estamos diante de uma invariante. A sociedade usa esta diferenciação para hierarquizar as atividades e os sexos. Em suma, segundo Hirata e Kergoat (2007: 596)"para criar um sistema de gênero(...) Esses princípios são válidos para todas as sociedades conhecidas, no tempo e no espaço. Podem ser aplicados mediante um processo específico de legitimação, a ideologia naturalista. Esta rebaixa o gênero ao sexo biológico, reduz as práticas sociais a 'papéis sociais' sexuados que remetem ao destino natural da espécie". 
Contudo, tentamos tratar esta invariante com cuidado, direcionando nossas reflexões no sentido de confirmar o que alega Kergoat (2009: 68):

"problematizar em termos de divisão sexual do trabalho não remete a um pensamento determinista; ao contrário, trata-se de pensar a dialética entre invariantes e variações, pois, se supõe trazer à tona os fenômenos da reprodução social, esse raciocínio implica estudar ao mesmo tempo seus deslocamentos e rupturas, bem como a emergência de novas configurações que tendem a questionar a própria existência dessa divisão".

E, para tanto, tivemos que nos agarrar ao diálogo entre esta divisão e o gênero, porque é este que produz significados para o sexo e para a diferença sexual, e não vice-versa.

Assim, por um lado, encontramonos com "flexibilidades estratégicas" por parte dos participantes da pesquisa, indicando vários trânsitos entre homens e mulheres pelos mundos claramente definidos como mundo de homens e de mulheres, o que poderia ter sugerido ausência ou pouca importância da divisão sexual do trabalho nas comunidades pesquisadas. Flexibilidades estas que incorporam a construção de territórios, jogos de valorações e valorizações em torno da renda monetária, dentre outros, gendrados, porque se trata, afinal, da criação, produção, reprodução, recriação constante de invariantes para a manutenção de um sistema de gênero.
Por outro lado, evidências de que estas flexibilidades podem estar presentes, dada justamente à força da intransigência das representações sociais sobre os gêneros, "as coisas que são de homem" e "as coisas que são de mulheres", ancoradas, por sua vez, materialmente, na "capacidade reprodutiva" (maternidade, cuidar, reprodução humana) das mulheres e na divisão sociossexual do trabalho.

\section{NOTAS}

${ }^{1}$ Programa Professor Visitante Nacional Sênior; Bolsa PQ-CNPq. O projeto de pesquisa contou com apoio do $\mathrm{CNPq}$, MDS e SPM-PR (Edital 20/2010).

2 O trabalho de campo de sua dissertação, aprovada em 2007 (UFPA/IECOS/ PPBA), foi realizado na mesma comunidade. Seu objeto de estudo foi a participação juvenil na pesca artesanal.

${ }^{3}$ Snowballsampling: amostragem em "bola de neve", ou "cadeia de informantes". Técnica de amostragem que utiliza cadeias ou redes de referência, seguindo indicações dos participantes da pesquisa (Biernacki \& Waldorf 1981).

${ }^{4}$ Pesca engloba a extração de peixes, caranguejos, mariscos (dentre outros, camarão, mexilhão, turus respectivamente-Crustáceos, Mytella, Teredosp). Entretanto, para facilitar a leitura, no texto será usada pesca para extração de peixe, tiração para pesca de caranguejo, coleta para outros mariscos e catação para o beneficiamento do caranguejo.

${ }^{5}$ Estuários são ambientes onde a água proveniente do mar se encontra com a água originária de um rio, e as águas doces e salgadas se misturam: ambiente muito rico e diverso em formas de vida. 
${ }^{6}$ É bastante frequente na região a ideia de entidades sobre-humanas, parte do que Maués (2005) indica como uma espécie de catolicismo popular, que mantém relações com o xamanismo nativo ("pajelança cabocla"), cuja origem se remete a antigas práticas e crenças dos índios Tupinambás, assim como a influências portuguesas e africanas. São encantados ou bichos do fundo, tais como a Mãe D’Água. Este ente surge da água doce, incluindo a de poços de água, hipnotiza ("flecha") a pessoa e a chama tentando afogá-la. A "flecha" provoca dores, febres, depressão. Há também os "encantados" do mangue e da mata, como é o caso do Curupira e da Matintaperera. Trata-se, em todos os casos, de seres perigosos, que podem provocar mau-olhado (sofrimentos como febre, depressão, dores, brigas familiares e separações matrimoniais) nas pessoas, ou fazer com que se percam na mata. Os serviços das curandeiras e das rezadeiras, além dos pajés, são bastante utilizados pela população (rezas, chás e fitoterápicos, rituais de proteção das casas, curas de enfermidades, etc.). O médico tende a ser o último a ser consultado.

\section{REFERÊNCIAS}

Alencar, E. F. 1993. Pescadeiras, companheiras e perigosas: a pesca feminina na Ilha dos LençóisMA. Dissertação de Mestrado. Departamento de Antropologia, Universidade de Brasília, Brasília, Brasil.

Almeida, M. P. 2002. Trabalhos femininos e papéis sociais em uma comunidade rural do nordeste do paraense, in No mar, nos rios e na fronteira: faces do campesinato no Pará. Organizado por J. Hébertte; S. B. Magalhães; M. C. Maneschy, pp. 56-84. Belém: EDUFPA.

Almeida, M. W. B. 1986. Redescobrindo a família rural brasileira. Revista Brasileira de
Ciências Sociais 1(1): 184-192.

Biderman, M. T. C. 1998. O dicionário padrão da lingua volume 28. São Paulo: UNESP.

Biernacki, P. \& D. Waldorf. 1981. Snowball Sampling: Problems and techniques of Chain Referral Sampling. Sociological Methods \& Research 2:141-163.

Blandtt, L. S. 2000. Sociedades humanas e o recurso caranguejo: cultura, economia e educação. Trabalho de Conclusão de Curso. Faculdade de Educação, Universidade Federal do Pará, Bragança, Brasil.

Bourdieu, P. (org.). 1997a. A miséria do mundo. Petrópolis: Vozes.

Bourdieu, P. 1997b. Razões práticas: Sobre a teoria da ação. Campinas: Papirus.

1979. O desencantamento do mundo: Estruturas econômicas e estruturas temporais. São Paulo: Perspectiva.

Brasil. 2000. Lei $\mathrm{N}^{\circ}$ 9.985, de 18 de julho de 2000. Institui o Sistema Nacional de Unidades de Conservação - SNUC.

2005. Decreto s/n, de 20/05/2005.

Dispõe sobre a criação da Reserva Extrativista Marinha de Caeté-Taperaçú, no Município de Bragança, no Estado do Pará, e dá outras providências. Disponível em: http://www.planalto.gov.br/ccivil_03/ revista/Rev_72/legislacao/decretos.htm. Acesso em: 01 de janeiro de 2013.

2007. Decreto No 6040, de 07 de fevereiro de 2007. Institui a Política Nacional de Desenvolvimento Sustentável dos Povos e Comunidades Tradicionais.

Bruschini, C. 2006. Trabalho doméstico: inatividade econômica ou trabalho não remunerado? Revista Brasileira de Estudos da População 23(2):331-353.

Camargo, M. \& V. J. Isaac. 2003. Ictiofauna Estuarina, in Os Manguezais da Costa Norte Brasileira. Organizado por M. E. B. Fer- 
nandes, pp. 105-141. Maranhão: Fundação Rio Bacanga.

Dedecca, C. S. 2004. Tempo, trabalho e gênero, in Reconfiguracõoes das Relações de Gênero no Trabalho. Organizado por A. A. Costa; E. M. Oliveira; M. E. Lima; V. Soares, pp. 35-55. São Paulo: CUT.

Delphy, C. 2009. Patriarcado (teorias do), in Dicionário crítico do feminismo. Organizado por H. Hirata; F. Laborie; H. Le Doaré; D. Senotier, pp. 173-178. São Paulo: UNESP.

Di Ciommo, R. C. 2007. Pescadoras e pescadores: a questão da equidade em uma Reserva Extrativista Marinha. Ambiente \& Sociedade 1: 151-163.

Diegues, A. C. 1995. Povos e mares: leituras em Socioantropologia marítima. São Paulo: NUPAUB-USP.

Diegues, A. C. \& R. S. V. Arruda. 2001. Saberes tradicionais e biodiversidade no Brasil. Brasília: Ministério do Meio Ambiente.

Durkheim, H. 2008. Da divisão do trabalho social. 3. ed. São Paulo: WMF Martins Fontes.

Ever, M. C. A. 2012. O lugar da mulher na apropriação e uso dos recursos naturais e nas atividades produtivas em Caratateua, Bragança, Pará, Brasil. Dissertação de Mestrado. Programa de PósGraduação em Biologia Ambiental, Universidade Federal do Pará, Bragança, Brasil.

Ferrugem, R. M. 2010. Relações de trabalho e parentesco: intercâmbios e flexibilidade na Associação de Artesãos de Novo Airão ANAA, in Mobilizaçōes étnicas e transformações sociais no Rio Negro. Organizado por A. W. B. de Almeida \& E. A. FARIAS Jr., pp. 426-444. Manaus: UEA Edições.

Fougeyrollas-Schwebel, D. 2009. Trabalho doméstico, in Dicionário crítico do feminismo. Organizado por H. Hirata; F. Laborie; H. Le Doaré; D. Senotier, pp. 256-262. São Paulo: UNESP.
Furtado, L. 1987. Curralistas e redeiros de Marudá: pescadores do litoral do Pará. Belém: Museu Paraense Emílio Goeldi.

Glaser, M. \& R. S. Oliveira. 2005. Direitos e deveres no comanejo costeiro do Brasil, in Gente, Ambiente e Pesquisa: Manejo Transdisciplinar no Manguezal. Organizado por M. Glaser; N. Cabral; A. L. Ribeiro, pp. 351268. Bragança: MADAM/ UFPA/NUMA.

Gorayeb, A. 2008. Análise integrada da paisagem na bacia hidrográfica do Rio Caeté - Amazônia Oriental. Tese de Doutorado. Departamento de Ecologia, Universidade Estadual Paulista, Brasil.

Henrique, R. 2005. A mulher e as relações de gênero em comunidades pesqueiras: o caso de Acarajó (Bragança, Pará), in Gente, ambiente e pesquisa: manejo transdisciplinar no manguezal. Organizado por M. Glaser; N. Cabral; A. Ribeiro, pp. 139-154. Belém: NUMA/UFPA.

Hirata, H. \& D. Kergoat. 2007. Novas configurações da divisão do trabalho. Cadernos de Pesquisa 37(132):595-609.

Hirata, H. \& P. Zarifian. 2009. Trabalho (Conceito de), in Dicionário Crítico do Feminismo. Organizado por H. Hirata; F. Laborie; H. Le Doaré; D. Senotier, pp. 251-256. São Paulo: Unesp.

Huntington, H. P. 2000. Using traditional ecological management knowledge in science: methods and applications. EcologicalApplications 10:1270-1274.

Jodelet, D. 1985. La representación social: fenómenos, concepto y teoría, in Psicologia Social. Organizado por S. Moscovici, pp. 469-494. Barcelona: Paídos. 2001. Representações sociais: Um domínio em expansão, in $A s$ representações sociais. Organizado por D. Jodelet, pp. 17-29. Rio de Janeiro: UERJ. 
Kergoat, D. 2009. Divisão sexual do trabalho e relações sociais de sexo, in Dicionário crítico do feminismo. Organizado por H. Hirata; F. Laborie; H. Le Doaré; D. Senotier, pp. 67-75. São Paulo: Unesp.

Krause, G., Schories, D., Glaser, M., Diele, K. 2001. Spatial patterns of mangrove ecosystems: the bragantinian mangroves of northern Brazil (Bragança, Para). Ecotropica 7:93-107.

Kuchemann, B. A. Enfoque de Gênero nas relações com populações do entorno das Unidades de Conservação. Diretoria de Unidades de Conservação e vida Silvestre. Disponível em: http:// www.ibama.gov.br/siucweb/guiadechefe/ guia/anexos13/index.htm. Acesso em: dezembro de 2000 .

Maneschy, M. C. 1993. Pescadores e curralistas no litoral do estado do Pará: evolução e continuidade de uma pesca tradicional. Revista Brasileira de História da Ciência 10:53-74.

1994. Uma presença discreta: a mulher na pesca, in Amazônia e a crise da modernização. Organizado por M. A. D’Incao; I. M. Silveira, pp. 251-9258. Belém: Museu Paraense Emílio Goeldi.

1995a. Ajurutena: uma comunidade pesqueira ameaşada. Belém: UFPA.

1995b. A mulher está se afastando da pesca? Continuidade e mudança no papel da mulher na manutenção doméstica entre famílias de pescadores no litoral do Pará. Boletim do Museu Paraense Emílio Goeldi. Série Antropologia 11(2):145-166.

Maneschy, M. C. \& C. Escallier. 2002. Parceiras de terra: o trabalho das mulheres na pesca em Vigia, litoral do Pará, in Gente e ambiente no mundo da pesca artesanal. Organizado por L. Furtado; G. Quaresma; D. Helena, pp. 57-90. Belém: Museu Paraense Emilio Goeldi.
Maneschy, M. C.; D. Siqueira \& M. L. M. Alvarez. 2012. Pescadoras: subordinação de gênero e empoderamento. Revista Estudos Feministas 20(3):817-837.

Marques, S. N.; E. A. Carvalho \& C. S. Mello. 1997. Levantamento preliminar das angiospermas de manguezal da estrada de Ajuruteua, município de Bragança (PA), in III Workshop Internacional sobre dinâmica e recomendações para manejo em áreas de manguezais de Bragança-PA. Resumos, pp. 3-4.

Mathieu, N. 2009. Sexo e gênero, in Dicionário crítico do feminismo. Organizado por H. Hirata; F. Laborie; H. Le Doaré; D. Senotier, pp. 222-231. São Paulo: UNESP.

Maués, M. A. 1993. "Trabalhadeiras" e "camaradas"; um estudo sobre o status das mulheres numa comunidade de pescadores. Belém: UFPA - Centro de Filosofia e Ciências Humanas. 1994. Quando chega essa "visita"? in Amazônia e a crise da modernização. Organizado por M. A. D’incao; I. M. Silveira, pp. 227-240. Belém: Museu Paraense Emílio Goeldi.

Moscovici, S. 1988. Notes towards a description of social representations. European Journal of Social Psychology 18:211-250.

Oliveira, M. V. 2013. Trabalho e territorialidade no extrativismo de caranguejos em Pontinha de Bacuriteua, Bragança, Pará. Dissertação de Mestrado. Programa de Pós-graduação em Biologia Ambiental, Universidade Federal do Pará, Belém, Brasil.

Paulilo, M. I. 1987. O peso do trabalho leve. Revista Ciência Hoje 5:75-93.

Paulilo, M. I. \& A. Brumer. 2004. As agricultoras do Sul do Brasil. Revista Estudos Feministas 12: 24-39.

Pinto, C. 2003. Uma história do feminismo no Brasil. São Paulo: Perseu Abramo. 2010. Feminismo, história e poder. Revista de Sociologia Política 18(36):15-23. 
Ramos, D. P. 2009. Pesquisas de usos do tempo: um instrumento para aferir as desigualdades de gênero. Estudos Feministas 17(3): 861-870.

Santos, C. N. 1992. A "luta da mulher rural pela cidadania". O caso de Acarajó, Bragançal PA - 1980 - 1990. Trabalho de Conclusão de Curso. Faculdade de Geografia, Universidade Federal do Pará, Bragança/PA.

Segato, R. L. 2005. Análise de gênero e elaboração de uma proposta para a estratégia de gênero do Programa da Cooperação Técnica Alemã para a Proteção e Gestão Sustentável das Florestas Tropicais. Texto inédito.

Scott, J. 2009. Preguntas no respondidas. Debate Feminista 20 (40): 100-139.

Scott, R. P. \& R. L. M. Cordeiro. 2007. Revista Estudos Feministas 15(2):102-129.

Souza-Filho, P. W. M. \& W. R. Paradella. 2002. Recognition of the main geobotanical features along the Bragança mangrove coast (Brazilian Amazon Region) from Landsat TM and RADARSAT-1 data. Wetl. Ecol. Manag. 10:123-132.

Souza-Filho, P. W. M. \& M. El-Robrini. 2000. Coastal zone geomorphology of the Bragança area, Northeast of Amazon Region, Brazil. Revista Brasileira de Geociências 30: 518-522.

Suárez, M. 2000. Gênero: uma palavra para desconstruir ideias e um conceito empírico e analítico. Trabalho apresentado no I Encontro de intercâmbio e do Fundo de Gênero no Brasil. CIDA/Fundo para a equidade de gênero. Brasília: inédito.

Weber, M. 1967. A ética protestante e o espirito do capitalismo. 9. ed. São Paulo: Pioneira.

1994. Economia e sociedade: fundamentos da sociologia compreensiva. Brasília: EdunB.

Wolf, M.; V. Koch; V. Isaac. 2000. Atrophic flow model of the Caete mangrove estuary
(North Brazil) with considerations for the sustainable use of its resources. Estuarine Coastal Shelf Science 50:789-803.

Woortmann, E. F. 1992. Da complementaridade à dependência: Espaço, tempo e gênero em comunidades pesqueiras. Revista Brasileira de Ciências Sociais 7(18): 134-148.

Recebido em 01/05/2013.

Aprovado em 06/08/2013. 